\title{
Serpica Naro and the Others. The Media Sociali Experience in Italian Struggles Against Precarity.
}

\author{
Alice Mattoni, European University Institute
}

\section{Introduction $^{1}$}

This article investigates a specific feature of recent Italian struggles against work insecurity: the specific forms of media that activists created as part of a transnational protest campaign, named the Euro Mayday Parade, which was inaugurated as a national protest event in 2001 and which spread to other European countries after 2004. ${ }^{2}$ The media in question are the so-called media sociali, the label used by their creators, the Chainworkers Crew, a fluid activist group based in Milan whose name refers to workers employed in multinational chain stores. The group formed in 1999 and immediately created its own webzine in order to promote 'media and mall activism for awarenessbuilding and unionization of precarious workers' (Chainworkers Crew n.d.-a). The Chainworkers Crew has focused from its inception on two main topics, communication and precarity, since many people involved in the group are, or have been, precarious workers employed in the communication and information sector. ${ }^{3}$

\footnotetext{
${ }^{1}$ I thank all the activists I interviewed for this article for sharing with me their narratives, thoughts and impressions. I am indebted to Donatella Della Porta, Massimiliano Andretta, Lorenzo Mosca, Simon Toubeau and Andrea Rashbrook for reading previous versions of this article, which were presented at the $6^{\text {th }}$ OURmedia Conference in Sydney, 9-13 April 2007, and at the IAMCR Conference in Paris, 23-25 July 2007. Finally, I would like to thank Ilaria Vanni and the two anonymous peer reviewers for their constructive critiques and suggestions.

${ }^{2}$ Here, the definition of protest campaign is 'a thematically, socially, and temporally interconnected series of interactions that, from the viewpoint of the carriers of the campaign, are geared to a specific goal' (Della Porta and Rucht 2002: 3).

${ }^{3}$ For a more detailed history of the Chainworkers Crew and its approach to political struggles against precarity, see Chainworkers Crew (2001).
}

PORTAL Journal of Multidisciplinary International Studies, vol. 5, no. 2, July 2008.

ISSN: $1449-2490$

http://epress.lib.uts.edu.au/ojs/index.php/portal 
The Chainworkers Crew and other activist groups that mobilized around the issue of precarity from 2001 were producers of symbolic resources, in that they also attempted to construct a collective identity in which various kinds of workers might recognize themselves. This happened in a specific discursive setting. In many European countries since the 1970s, the unemployment emergency and the structural economic crisis has seen the parallel affirmation of what Beck defines as the 'labour market flexibility political mantra' (2000: 3), and what Botalnski and Chiapello (2005), speaking of France in the 1980s, call a 'narrative' related to a process apparently 'willed by no one' (2005: 194). In Italy, this dominant discourse was matched by legislative measures that rendered the labour market more and more flexible. While this process began in the 1980s, with decrees and laws ostensibly intended to deregulate salaries and make them more flexible, since the 1990s the legislative focus has been on ensuring labour market flexibility, especially with regard to market entry (Fumagalli 2006: 131-34). ${ }^{4}$

In that context, activists and workers have increasingly singled out a new social subject, precarious workers at the centre of a new social problem, precarity. The latter has been defined as a situation 'which describes an increasing change of previously guaranteed permanent employment conditions into mainly worse paid, uncertain jobs. In this sense, precarity leads to an interminable lack of certainty' (Neilson and Rossiter 2005). The term precarity is not completely new in Italian society, and has earlier incarnations in the social movement mobilization of the 1970s (Grispini 2006). However, in recent decades it has been linked strictly to new forms of labour characterized by a high degree of worker flexibility and a large number of bargaining models, all of which contribute to strong labour market segmentation. ${ }^{5}$ Since precarious workers experience different working conditions, a number of conceptions of the term precarity, as well as claims made about and proposed solutions to the problem, emanate from various precarious workers groups or coalitions. Nonetheless the Italian activist groups that mobilized around precarity share one characteristic: they comprise social agents able to elaborate alternative systems of meanings through their use of innovative languages and creative activist practices (Melucci 1996). In this regard, the media sociali appear to be the

\footnotetext{
${ }^{4}$ According to Gallino (2007: 63-71), four main legislative measures were responsible for increasing work precarity in Italy: the intergovernmental agreement in 1993; the Law of June 24, 1997, no. 197, commonly named the 'Pacchetto Treu'; the Legislative Decree of September 6, 2001, no. 368; and the Law of February 14, 2003, no. 23.

${ }^{5}$ Today the Italian labour market is one of the most flexible in Europe with some forty fixed term contract options available to workers (Fumagalli 2007: 28).
} 
clearest attempt in recent Italian history to impart a fresh imagery to the issue of work insecurity, by combining guerrilla communication tactics with the construction, or reinforcement, of political relationships between precarious workers and activists. One well-known example of a parallel symbiosis between creative political tactics and relationships would be culture jamming, which 'involves the grassroots reworking of existing media images and media forms to change their meaning, to call attention to what may otherwise go unnoticed, to implicate those images in broader political issues' (Meikle 2007: 177).

Noting the need for more studies of this phenomenon, this article focuses on media sociali in order to identify the main activist mechanisms on which they depend. ${ }^{6}$ In particular, I argue that media sociali are not simply important innovations from an aesthetic point of view; they also signal an interesting attempt to foster political socialization and precarious workers' collective identity alike. As Ilaria Vanni (2007) argues, social media like the Imbattibili or San Precario do not only contribute to the precarious workers' identity narration. They also play a crucial performative role at the political level. My approach here builds on that understanding and is predicated on a broad definition of alternative media, conceived as 'media production that challenges, at least implicitly, actual concentrations of media power, whatever form those concentrations may take in different locations' (Couldry and Curran 2003: 7). As other authors stress, these types of media challenge media power in two ways: by producing and circulating systems of meanings that are alternative to dominant ones; and by empowering people who are directly involved in their creation and diffusion. As a consequence, media sociali might produce social change at the micro level of individuals (Atton 2002; Rodríguez 2001; Duncombe 1997). Alternative 'media practice' (Couldry 2004) thus serves as a relational site of empowerment, rather than simply providing a venue for presenting radical content.

In investigating the media sociali, this article provides an analysis of the social practices through which such media are produced, diffused and eventually perceived,

\footnotetext{
${ }^{6}$ See Vanni (2007) for analysis of the Imbattibili, and Tarì and Vanni (2005) for analysis of San Precario. An earlier contribution to work on alternative media activism in Italy is Downing (2001), who analyzes the creation of such alternative media as Il Manifesto, a national newspaper, Radio Popolare and Controradio, two local free radio stations. However, they were established in past cycles of mobilization, that is to say, during the 1960s and the 1970s.
} 
appropriated, and sometimes readapted in the social movement milieu where they are rooted. This last point allows my analysis to present a more complete, though not exhaustive, picture of the media sociali and thus to highlight some of the challenges that alternative media practices imply. I proceed by providing a brief note on the methodology used during the investigation. I then discuss the broader context of the Euro Mayday Parade in which the media sociali developed; my focus here is on the period between 2001 and 2006, when the parade reached its peak. This focus also reflects the fact that the media sociali I investigate were developed in 2004 and 2005. Finally, I examine the construction process of three specific forms of media sociali, including their theoretical elaboration by activists and their reception within the Euro Mayday Parade: the invention of the San Precario icon; the conception of the Serpica Naro fashion show; and the creation of Imbattibili sticker cards.

\section{A note on methodology}

Activists who create media sociali are engaged in collective self-reflection about their media practices and the production and circulation of knowledge related to those practices. Analysis of the self-reflexive practices deployed in such social movements

presents researchers with a number of methodological challenges or choices. The first choice is related to the term media sociali itself, used throughout the article in preference to alternative terms that also refer to media practices beyond mainstream media, such as 'radical media' (Downing 2001), 'alternative media' (Atton 2002), 'citizen media' (Rodriguez 2001), 'activist media' (Waltz 2005) or 'autonomous media' (Langlois and Dubois 2005). This preference is not merely semantic. Rather, it implies a perspective emanating from within specific social movements and, by extension, an attention to activists' own material decisions and voices. The second choice is related to the need to go beyond the descriptive register in order to connect activists' narratives, reflections and perceptions in broader historical frameworks. Extant literature on alternative media assists me here not only in positioning media sociali in the arena of alternative 'cultural production' (Atton 2002: 29), but in grounding media sociali in the Euro Mayday Parade and the attendant controversial debates that circulated among the participating activists groups.

I utilise two main sets of data sources about media sociali, aside from the media themselves. The first set includes activists' media texts, such as video reports, 
documentaries, radio programs and websites related to the Euro Mayday Parade and the creation of media sociali. The second set of data consists of semi-structured narrative interviews with activists that assist in reconstructing the development of media sociali and their structures. Both sources shed light on activists' perception of their own media practices, and on how media sociali have become organic modes of expression in which a variety of experiences and viewpoints meet. In researching this article, I interviewed two groups of activists: activists and precarious workers who participated directly in the invention and development of media sociali; and activists who contributed to the organisation of the Euro Mayday Parade without contributing to media sociali creation. ${ }^{7}$

\section{The contentious political context}

Media sociali are rooted in the Euro Mayday Parade, a protest campaign that culminates with a mass parade in numerous European cities on May 1 each year. The first parade took place in Milan, Italy, in 2001, under the name Mayday Parade. In its early incarnation, the parade was a local phenomenon involving local organisations, but with only a few activists involved directly in its organization. Three political groups based in Milan created the parade: a group of self-organized precarious workers, the Chainworkers Crew; a group of activists from a social centre, Deposito Bulk ${ }^{8}$; and a radical trade union, the Confederazione Unitaria di Base (CUB). ${ }^{9}$ Since its inception the parade has evolved into a national and subsequently transnational protest campaign involving thousands of people across Europe. In 2004, it changed its name to the Euro Mayday Parade, with simultaneous parades organised in Milan and Barcelona, and other parades or direct actions against precarity taking place in Palermo, Dublin and Helsinki. The 2004 parade poster emphasised this transnational network by using several languages_-French, Italian, Spanish and English — and by championing 'European

\footnotetext{
${ }^{7}$ Specifically, I conducted five interviews with Chainworkers Crew activists and ten interviews with activists involved in the Euro Mayday Parade. Each interview lasted about one hour. Their transcripts were analysed through computer assisted discourse analysis using Atlas.ti software, and involved a mix between in vivo coding and predetermined code lists.

${ }^{8}$ The Deposito Bulk was a social centre active in Milan from 1997 to 2006. Social centres, centri sociali in Italian, are abandoned buildings occupied by groups of people in order to have a space to promote underground cultures and offer auto-organized services to the neighbourhood in which they are located. In some cases, social centres are also spaces in which activists live.

${ }^{9}$ The CUB is a radical trade union that was created in 1992 by a group of workers who did not recognize themselves in traditional trade unions. According to Della Porta and Mosca, radical trade unions in Italy 'emerged during the 1990s from a series of labour mobilizations. In their forms of action, organizational formulas and discourses, they differed from the three traditional, confederate trade unions - the leftwing CGIL, the Catholic CISL and the UIL — not only in their critique of neo-liberal reforms, but also in their emphasis on direct action, participative democracy and 'class identity'" (2007: 6).
} 
social rights' (Euromayday Network 2004). Furthermore, a transnational network of European activists formed during the so-called 'Beyond the ESF' forum, an event organized at the Middlesex University by the group Wombles in opposition to the European Social Forum. ${ }^{10}$ Since 2004 there has been a proliferation of preparatory meetings and assemblies, at both national and transnational levels, with the result that in 2005, the Euro Mayday Parade was organized in seventeen European cities, while in 2006, the Parade's peak year, it involved eighteen cities. ${ }^{11}$

The main aim of this protest campaign was to provide visibility to precarious workers, to establish a composite collective identity for this new social subject, and to claim new social rights for precarious people all over Europe. The campaign was based on new languages, symbols and icons directly related to precarious workers and precarity. Indeed, one of the main characteristics of the Euro Mayday Parade was the important role of the symbolic and of activists' concomitant involvement in a number of media practices. Participating activists sought to ensure that the Parade received mainstream media coverage by organising traditional activist strategies, such as press conferences, and staging political actions at the Parade's launch. At the same time, activists engaged in the construction of various forms of alternative media, such as informational websites, free radio broadcasts through the Internet, and video documentaries about the Parade and other struggles against precarity. In short, activists tried to represent the Euro Mayday Parade and related contentious issues in autonomous ways within the mediascape, and without institutional political mediation.

While its symbolic impact has been crucial to its history and success, the Euro Mayday Parade evolved into something more than a parade against precarity by redefining the spaces and languages of European activism in general. Some authors refer to it as a public space in which meet various activist groups that share a common interest in

\footnotetext{
${ }^{10}$ The European Social Forum 'is the regional version of the World Social Forum, which provides an arena for encounters and debates to large number of organizations and activists from different countries' (Della Porta 2007: 3). In 2002, the first European Social Forum took place in Florence. In subsequent years it occurred more or less annually in different European cities: Paris in 2003, London in 2004, Athens in 2006, and Malmo in 2008. Increasingly many grassroots activist groups have blamed the European Social Forum for being too institutionalized, not horizontal in its organization, and not radical enough. This critique provided the motivation for organizing a parallel forum in the same city hosting the European Social Forum (Agrikoliansky \& Sommier 2005), like the one organized by the activist group Wombles.

${ }^{11}$ While the Euro Mayday Parade continues to take place, this article focuses on its operations in its first five years.
} 
struggling against precarity (Curcio and Visco 2005: 19). The Euro Mayday Parade can be seen, then, as a protest campaign able to open a common space of discussion and action that was strongly oriented towards politics. Many activist groups, sometimes belonging to different cultural and political traditions, regularly met during preparatory meetings, discussed tactics through mailing lists, and eventually convened to protest in the same physical space. In this way the activists developed a novel language about working insecurity, thanks to the elaboration of fresh signifiers and meanings they created that related to precarious workers and their labour.

The Euro Mayday Parade was an open space in the sense that, in theory, each activist group could propose its own interpretation of political conflict and radical communication, and then participate in the Parade according to its own 'repertoire of action' (Tilly 1978). In 2004, for example, direct actions against banks and private temporary employment agencies went hand in hand with activists performing a samba concert dressed with pink clothes on the streets of Milan. Moreover, this participatory space not only evolved as the years went by but also produced specific outcomes. For instance, it was possible that in this space new networks among activist groups could emerge and inspire collaboration at more institutional, long term levels. This occurred in Lombardy with the creation of a regional network against precarity that proposed a law for the introduction of regulated social income (Rete regionale contro la precarietà e la legge 30 2005). ${ }^{12}$ In this case, the Euro Mayday Parade empowered activist groups through new political actions, connections and networks that went beyond the protest campaign itself. Therefore, even the presence of difficulties, such as internal clashes and misunderstandings between activist groups, could be interpreted as a defining characteristic of the political space presented by the Euro Mayday Parade. Thus one of the productive outcomes of the intensive, radical and disruptive political processes at work in this space seems to have been the competition between alternative discourses about precarity and the definition of what, in fact, a political struggle should be and how it should proceed. And in this specific activist space the creation and diffusion of the media sociali occurred.

\footnotetext{
${ }^{12}$ The network included non-institutional political subjects who invented and/or participated in the Euro Mayday Parade, such as the Chainworkers Crew and the radical trade union Sincobas, as well as institutional political subjects like radical left wing political parties and some sections of traditional trade unions.
} 


\section{Media Sociali at Work}

The media sociali were a particular kind of media practice intended to abet political socialization and contribute to the broad social dissemination of imagery about precarious workers. The Chainworkers Crew did not predetermine, at the theoretical level, the process of elaboration that lead to these desired outcomes. Rather, the need to develop new tools that could speak of precarity to precarious workers and beyond them was the starting point of the group's experimental practices, which tried to combine political conflict with autonomous media practices. In other words, there was no real separation between the theoretical moment and practical, direct experience. Between 2004 and 2006, the Chainworkers Crew discussed and wrote a series of articles that focused on the concept of media sociali. These articles, collected in a reader in October 2006, synthesised the thinking that the Chainworkers Crew developed in the process of media sociali creation, thereby enriching their media's meanings at the theoretical level and proposing a self-reflection about the role of alternative imageries in the neo-liberal era. In one of their articles the Chainworkers Crew defined the media sociali as follows:

The form of communication born from the particip-activism of precarious [people], which has no reference to commercial reproduction. [The media sociali are] able to represent them and, at the same time, to constitute a form of conspiracy that may not be summed up and re-worked by neoliberal means of production. The media sociale hangs on the mainstream media, by infiltrating each of their gorges and by appearing as something that is neither homologous with nor reducible to profit. (Chainworkers Crew 2006: 28) ${ }^{13}$

At one level the media sociali represented a cumulative set of media practices, which slowly evolved and redefined themselves. On another level the media sociali became a set of concepts based on progressive knowledge processes, which inspired reflections on new means of dealing with and understanding political conflict. The next paragraphs elaborate on these features of media sociali by focusing on three concrete examples elaborated by the Chainworkers Crew in 2004 and 2005: the patron saint of all precarious workers, San Precario; the false fashion designer Serpica Naro; and the sticker cards of the Imbattibili.

\section{San Precario, the patron saint}

San Precario appeared for the first time on February 29, 2004, at the COOP supermarket in a suburban neighbourhood of Milan. There, activists dressed up as priests, monks and

\footnotetext{
${ }^{13}$ Translation from Italian by the author.
} 
nuns, intoning the San Precario prayer (Chainworkers Crew n.d.-b), formed a procession bringing a statue of the patron saint to the supermarket where they distributed a small saint card to customers. Finally, activists announced that the saint had decided to perform a miracle, namely a $20 \%$ reduction on prices for everyone in the supermarket. Cashiers were blocked from intervening. The unusual event confirmed itself as a direct action against both worker precarity and the constant price increase of goods (Reload Video Crew 2004).

From the very beginning of its creation, San Precario was highly symbolic.

Significantly, the saint was 'born' on February 29, a date that recurs only once every four years and hence sardonically evokes many forms of non-continuing work (Tarì and Vanni 2005: 26). More importantly, this example of media sociali clearly referenced the Italian Catholic tradition characterized by the presence of saints, subverted its main codes, and provided a floating signifier able to reproduce a strong imagery in different contexts (Tarì and Vanni 2005: 27). According to one interviewee, Andrea, who was involved in the creation of San Precario, the diffusion of San Preacario's image was linked to a process that 'was not a matter of identification, but of recognition and imagery construction. Thus the first creation was San Precario, which was born to some extent by chance. And then it really became popular in the sense that after fifteen days there were people from Canada who asked for the saint cards. ${ }^{14}$

As Andrea also stressed, San Precario moved into spaces quite distant from that of its origins. Besides spreading into other countries, the patron saint of all precarious workers was used in Italy in a range of contexts. An example of this was the movie sponsored by the traditional trade union CGIL and other left-wing associations, Il Vangelo Secondo Precario, in which four young precarious workers struggle against their daily precarity, and the San Precario character is transformed into 'Sandro Precario,' a dead boxer who, from heaven, tries to help precarious workers. ${ }^{15}$ Another interesting example was the use of the San Precario image on the cover of the book, San Precario, Workfor Us, by the sociologist Accornero (2006: 67), in which the author highlights the questionable

\footnotetext{
${ }^{14}$ All the interview extracts are translated from the Italian by the author. Andrea was an activist in the social centre (ex) Deposito Bulk. When he was interviewed, Andrea was a precarious worker. He was interviewed in his flat in Milan on December 18, 2006. The names of all the interviewees in this article have been changed for privacy reasons.

${ }^{15}$ The English translation of this film title is 'The Gospel According to Precario.'
} 
differences between precarity as perceived by Italian citizens (that is high) and precarity as it can be actually measured in Italian society (that is low).

San Precario's image and message also spread at an individual level among precarious workers and ordinary people. Another interviewee, Carlo, who was also involved in the creation and distribution of San Precario, stressed that: 'to invent the San Precario icon and to create the saint cards allow it to become a real virus. In the sense that I began to find people who I've never seen, who I've never met ... who had the saint card in their pocket, in their wallet. ${ }^{16}$ The spread of the San Precario image among precarious workers who were not involved in any political struggle thus obeyed viral logics, as Carlo noted. This particular pattern of diffusion is similar to the one explained by Johan Peretti when speaking about the 'meme,' a term invented by the biologist Richard Dawkins to designate a 'unit of cultural transmission ... spreading from brain to brain' in an exponential way, due to the support of social networks (quoted in Peretti 2001). Paralleling the example of a meme at work identified by Peretti, a worldwide campaign against the Nike company that originated in a private email sent by the author, the San Precario meme also acted as a potential catalyst for political socialization. For the Chainworkers Crew, it enabled mutual and immediate recognition between the people who exchanged it that they shared a precarious working and living condition. As one activist, Verena, describes it, 'everyone to whom I gave the small holy picture had not only an amused look, but also recognition in his or her eyes. It happens to get the same reaction from an out-and-out Marxist-Leninist militant as well as from people outside any kind of political logic., ${ }^{17}$ Many of the interviewees emphasized that the Chainworkers Crew invented the San Precario icon to produce a common imagery for precarious workers who could not recognize themselves in the older workers categories at the centre of previous cycles of protest in Italy. The inventors of the small saint card conceived it as a particular form of leaflet by which the concept and reality of precarity could be presented through simple words and a catchy aesthetic, the aim being to communicate new understandings of precarity to precarious workers who were not socialized to political struggles. San Precario, then, was more than a simple icon able to shape representations of precarious workers, since it also had the potential to facilitate

\footnotetext{
${ }^{16}$ Carlo, a member of the Chainworkers Crew, was also a precarious worker when he was interviewed. The interview took place in his flat in Milan on December 21, 2006.

${ }^{17}$ Verena is an activist participating in the Chainworkers Crew and was a precarious worker when she was interviewed. The interview took place in her flat in Milan on January 25, 2007.
} 
political socialization and assist in mobilization around particular struggles.

This happened on a more regular basis within the social movement milieu, where the icon of San Precario was used in different contexts. In particular, the participation in the Euro Mayday Parade was important in the diffusion of the San Precario icon beyond the Parade. This is probably because participating activist groups were not simply sensitive to the precarity issue, but were linked by pre-existing channels of exchange anchored in the Euro Mayday Parade network, such as mailing lists, assemblies and the like. The existence of a ready-made social network of activists groups and individuals was crucial for sustaining the dissemination of San Precario as a meme. However, its broad spread was also possible because activists considered the media sociali to have no copyright. The icon's circulations were thus characterized by a process of 'distributive use ... concerned with the deliberate decentralization and relinquishment of control of the processes of reproduction and distribution of alternative publications by their original publishers' (Atton 2002: 42), a common approach in the alternative media realm. Activists thus conceived the media sociali either as 'copyleft brands' (San Precario), or as brands protected by a creative common license (Serpica Naro, of which more later). Media sociali were presented as belonging to all precarious workers and activists, who could thus use, reproduce and readapt them without limits.

The Chainworkers Crew invented the patron saint of precarious workers, which was then inserted into the broader Euro Mayday Parade space and eventually re-contextualized along various local nodes at the territorial level, enriching the activist repertoire of other groups linked to the Parade. For instance, various activist groups, in particular those belonging to the (ex) Disobbedienti Network, used the San Precario icon and statue in a range of political actions against precarity that they called the San Precario appearances. These appearances occurred all over Italy in supermarkets, shopping malls, bookshops and other venues between 2004 and 2005. The diffusion involved not only the San Precario icon, but the entire system of signifiers linked to it and reproduced during direct actions, as happened with San Precario's first appearance at the COOP supermarket in February 2004. ${ }^{18}$ As Couldry (2000: 162) observes, speaking of the Brightlingsea animal exports protests in the UK, such activist interventions modify the very places-

\footnotetext{
${ }^{18}$ For a partial list of the San Precario appearances see Global Project (2004).
} 
supermarkets, bookshops and so on-in which they occur by turning them into 'sites of discourses,' or, better said, sites of political discourses.

Moreover, at the level of grassroots unionism, various political collectives and social centres decided to open so-called San Precario protest points in order to inform precarious workers about their working rights and to help them overcome potential problems in their workplaces (San Precario n.d.). The San Precario icon was thus reinterpreted in very specific contexts of struggle. For example, a group of Alfa-Romeo workers opposed to the closure of a plant in a city near Milan invented their own protector saint, San Romeo, which as an interviewee, Domenico, explained, signified the adaptation of the San Precario icon for new ends:

The Alfa-Romeo workers invented Romeo after San Precario. Romeo was a woman disguised as a man, in short a mannequin ... He was dressed like a metalworker, with a wheel in his hands. He took part in demonstrations. So, let us say that to some extent San Precario reached the Alfa-Romeo workers, who continued this idea through Romeo, which was a way to represent a different kind of precarity. ${ }^{19}$

The invention of San Romeo is significant in exposing the connective mechanisms of diffusion between new activists groups working in loose network structures, such as the Chainworkers Crew and the Euro Mayday Parade network, and older and more institutionalised social movements' organizations, such as radical trade unions (Tilly and Tarrow 2006). ${ }^{20}$ The spread of such imagery about precarity nonetheless required the insertion of novel communicative tools into an established repertoire of action: the AlfaRomeo workers brought San Romeo into processions during strikes and pickets, just as activists used the San Precario icon to represent precarious workers during direct actions in supermarkets. The San Precario icon, then, seemed to succeed mainly at the communicative level. The lack of representation of precarious workers by established, institutionalized political subjects was overcome through the construction and development of a series of icons that became the symbols of independently organized struggles against precarity.

\footnotetext{
${ }^{19}$ Domenico is a radical unionist working at the CUB. The interview took place in his office near Milan on January 25, 2007.

${ }^{20}$ The examples mentioned above show the diffusion of San Precario within the Euro Mayday Parade at the local and national level in Italy. There are also similar examples at the transnational level. For instance, Spanish activists in Barcelona invented the icon of Nuestra Señora de la Precariedad, which is also intended to work with and subvert Catholic tradition. With regard to the European dimension of the Euro Mayday Parade, it is also possible to speak of cross-national diffusion processes (McAdam and Rucht 1993).
} 


\title{
Serpica Naro, the fashion designer
}

The name Serpica Naro, an anagram of San Precario, referred to a false Anglo-Japanese fashion designer created by the Chainworkers Crew for a real fashion show during Milan fashion week at the end of February $2005 .{ }^{21}$ While a small number of activists managed the invention of the San Precario icon and then successfully proposed it to the broader social movement milieu, the creation of Serpica Naro was a more complex affair, and involved dozens of activists and precarious workers.

The first goal of this example of media sociali was to subscribe Serpica Naro to the list of young fashion designers at the Camera della Moda, the Italian institution that controls Milan fashion week. At this stage in the campaign, pre-existing relationships between precarious workers employed within the fashion institution and activists were crucial, as the participant Daniela explained:

\begin{abstract}
The initial input came from some people who were involved and knew some dynamics related to the Camera della Moda selection procedure. Then they aired the possibility of entering this circuit and succeeding in organizing this bluff. Because insiders, who knew the mechanisms, revealed that this official institution, the Camera della Moda, was a big bluff in itself. It presented itself as competent abroad and in Italy, while as usual, it was managed by incompetent and ill-informed people. ${ }^{22}$
\end{abstract}

The Chainworkers Crew, together with precarious workers involved in the fashion system, managed a first phase in which they planned Serpica Naro's appearances in a meticulous way. The second phase began once Serpica Naro was successfully registered with the Camera della Moda. Activists invented a press office managed by the false journalist Nadja Fortuna, who kept contacts with the Camera della Moda and the press. The activists also produced fake press releases, the official Serpica Naro website, and a fake website that specialized in fashion news, which contained extensive features about the young Anglo-Japanese fashion designer.

The Chainworkers Crew then orchestrated a dispute between Serpica Naro and the activists themselves, who blamed the fashion stylist for exploiting the life style of precarious workers to produce her clothing line. Activists organized parallel demonstrations against Milan fashion week and, in particular, against two Italian fashion

\footnotetext{
${ }^{21}$ For detailed information about the Serpica Naro fashion show see Chainworkers Crew (n.d.-c).

${ }^{22}$ Daniela is an activist involved in the Chainworkers Crew and was a precarious worker when she was interviewed. The interview took place in a restaurant in the Isola neighbourhood of Milan on December 22, 2006.
} 
stylists, Laura Biagiotti and Prada. These protests used a stereotyped version of a particular repertoire of action, as Carla, another participant, explained:

\begin{abstract}
Within Fashion Week we created protest situations against other fashion designers, which were genuine, but took place in a manner that does not absolutely belong to the Chainworkers Crew. They were 'old style' actions, with smoke bombs, megaphones and the like. And to some extent they were useful to increase the tension a little bit and to say that this collective, which was carrying on a series of protests, will announce an impressive action against Serpica Naro as its last protest. ${ }^{23}$
\end{abstract}

With these tactics, the Chainworkers Crew subtly mocked a particular repertoire of action reminiscent of the 'old style' political actions that they were trying to break away from. However, the police was alerted to the possibility of disruptive actions against the Anglo-Japanese fashion designer, and so were journalists.

The final action was the creation of the fashion show itself, which was designed to appear as 'real' as possible. Independent, underground fashion designers created their own clothes collections for the show. Activists also invented a series of ad hoc, ironic clothes in order to solve daily precarious workers problems, such as working wear suitable for pregnant women who do not want their condition to be discovered by their employers in order to keep their jobs. The material construction of the fashion show setting was possible thanks to the cooperation among activists and a range of precarious workers employed in the fashion industry. This cooperation developed through a word by mouth mechanism predicated on secrecy and trust, and able to involve people with no direct links to the Chainworkers Crew. As a result, dozens of precarious workers took part in the Serpica Naro fashion show preparation, as the interviewee Marisa emphasized: 'We had a great help really from so many insiders to the fashion circuit. For instance, the red carpet on the catwalk was given to us by a person who worked in a chain store and who took it from the chain store warehouse. People really far away from us who, perhaps through friends and a scattered conspiracy, even gave us ... 50 disposable paper cups. ${ }^{24}$

Three categories of precarious workers participated in this 'scattered conspiracy' against

\footnotetext{
${ }^{23}$ Carla, a member of the Chainworkers Crew, was a precarious worker when she was interviewed. The interview took place in her flat in Milan on January 25, 2007.

${ }^{24}$ Marisa was an activist who participated to the Chainworkers Crew during the preparation of Serpica Naro and a precarious worker when she was interviewed. The interview took place in her flat in Bologna on January 23, 2007.
} 
the Milan fashion week: people belonging to the authorized staff of the Milan fashion week; people engaged in the independent production sector; and precarious workers employed in other market sectors. Therefore, Serpica Naro mobilized many individuals and established a dispersed but efficient network of people in the production of new imagery of precarity. According to Marisa: 'There was an increase and a subterranean vein of rebellion, which involved many people within and outside the city. They were neither activists nor particularly informed people. They were people who experienced not only a series of precarious situations, but also problems simply related to work.' The last stage was the Serpica Naro fashion show, when activists revealed that it was a hoax intended as a political action against precarity. ${ }^{25}$

The most important feature of this media sociale was its strong potential as a new model of political socialization. In this Serpica Naro was similar to San Precario, but it was based on different premises. With the collective creation of Serpica Naro, activists aimed to activate new relationships between activists and precarious workers who were not normally involved in political claims, and for whom, as a result, the term precarity might acquire a more radical and politicized meaning. Extending from the San Precario icon, then, the Chainworkers Crew adopted a new approach to media sociali development. The Serpica Naro fashion show was intended to resonate beyond the Chainworkers Crew in the hope of creating a distributed network of activists and precarious workers: this was not only an objective, but also a means to disseminate the discourse around precarity among non-politicized precarious workers. The creation of intense, though temporary, links among the various social actors involved in the fashion show preparation made visible a mechanism of social networking for a common political action.

Despite the fact that all the interviewees I spoke to recognized the importance of developing a shared imagery about precarious workers, some among them harboured doubts about media sociali. For example, activists belonging to the (ex) Disobbedienti Network, in whose repertoire of action civil disobedience and direct actions still have a crucial role, raised criticisms about the efficacy of these actions. However, while they

\footnotetext{
${ }^{25}$ After the staged fashion show, activists transformed Serpica Naro into a particular kind of 'copyleft' brand, protected by a specific creative commons license. They also developed an on-line community that intends to gather groups of people engaged in independent clothing production. Although the discourse about intellectual property rights was very important in the Serpica Naro development, this article investigates only the early stages of this media sociale (Chainworkers Crew n.d.-c).
} 
did not question the media sociali communicative style and aesthetic level per se, they did not consider them to be a sufficient means for constructing an incisive political struggle. For instance, according to the interviewee Fabio: 'a contentious action like the one of Serpica Naro, let's say the trick that was played on the institutional fashion shows, is difficult to be repeated; in fact I would say that it is not repeatable. Probably it was not its goal to provide a new element in the way in which [political] struggles are handled. ${ }^{26}$

Understanding the efficacy of the Serpica Naro fashion show and other media sociali seems to be linked to different interpretations of the very term political struggle. Contrary to Fabio's observations, another interviewee, Lorenzo, interpreted the media sociali as 'the most advanced answer to the auto-organization of communication and the auto-organization of struggle. In the sense that media sociali are a mechanism of conflict per se. Not only a mechanism of communication, but a means of struggle. ${ }^{27}$ In other words, media sociali do not merely provide a repertoire of action, but also raise questions about what specific forms of protest may produce within and outside the social movement milieu. It is interesting to note that the activist perception of media sociali seems to reflect greater and deeper gaps in contemporary Italian social movements. These are to some extent represented in the Euro Mayday Parade network as well. Another interpretation of these divergent opinions about media sociali in the Euro Mayday Parade could be that they reflect the limited general socialization and hence understanding of the underlying concepts of media sociali on the part of participating activists. For example, interviews confirmed that while the term media sociali is not part of the common language in the Euro Mayday Parade, activists involved in the Parade do know San Precario, Serpica Naro, and the Imbattibili. Thus, although some of the practices and dynamics on which the media sociali rest are reproduced in different contexts of struggle, their conceptual application is only developed and extensively known among the activists with direct connections to the Chainworkers Crew.

\section{Imbattibili, the super-heroics}

The Imbattibili were nineteen sticker cards distributed during the Euro Mayday Parade along with a sticker album. This form of media sociale could be read as a simple

\footnotetext{
${ }^{26}$ Fabio is an activist involved in the (ex) Disobbedienti Network and a precarious worker when he was interviewed. The interview took place in his flat in Marghera on November 9, 2006.

${ }^{27}$ Lorenzo is an activist involved in the Chainworkers Crew and he was a precarious worker when I interviewed him. The interview took place in his flat in Milan on December 22, 2006.
} 
evolution of the San Precario icon: its language has a similarly ironic register, and the catchy aesthetic also attempts to resemanticize pecarity in positive ways. For instance, one sticker represents 'Supeflex,' a worker who has experienced every available fixed term contract, which have influenced the development of new super-abilities: 'Stress leads to a pleasant mutation of her/his own molecules, developing the more hidden skills of her/his own brain: in fact, she/he is able to mentally communicate with all superflexs, starting the universal precarious conspiracy' (Chainworkers Crew n.d.-d).

The name Imbattibili is a parody of the Disney-Pixar movie, The Incredibles, and the reference reflects a specific intention, as the interviewee Laura notes: 'The Imbattibili are not super-heroes. Each of them is like a precarious worker who has to cope with contingent situations, drawing out his or her best, namely the human force that one has, and in this way is truly super heroic and not an unreachable super-hero. ${ }^{28}$ Activists distributed the sticker cards of Imbattibili during the Euro Mayday Parade, a parallel to the distribution of the San Precario saint card during the direct action in the COOP supermarket in 2004. There was thus a certain degree of continuity with previous media sociali. It was not by chance that both San Precario and Serpica Naro were also two of the Imbattibili characters. Nonetheless, as another interviewee Michele pointed out:

\footnotetext{
The Imbattibili have been a good step, since they moved from the unique and individual dimension. Because there is San Precario, who is a man with an androgynous image, but always a man, and Serpica Naro, a woman. But we are still in the duality of sexes [with those two images], and eventually [the Imbattibili provided] multiple images of subjects and references. ${ }^{29}$
}

With this action the Chainworkers Crew decided to stress the fact that precarious workers may experience very different working and living conditions and thus are composite social subjects. This reflects the nature of the Euro Mayday Parade, in which a variety of political subjects express their own territorial struggles. The Chainworkers Crew thus created the Imbattibili to give visibility to a loose and scattered network of small groups of activists or ordinary people who daily struggle against precarity. As with the Serpica Naro action, the Imbattibili implied the strengthening of relationships among different activists and precarious workers groups in Milan and its neighbouring

\footnotetext{
${ }^{28}$ Laura is an activist involved in the Chainworkers Crew. She had a continuing contract when she was interviewed. The interview took place in a restaurant in the Isola neighbourhood of Milan on December 22, 2006.

${ }^{29}$ Michele was an activist of the (ex) Deposito Bulk and a precarious worker when he was interviewed. The interview took place in his office in Milan on December 19, 2006.
} 
regions. The idea was to involve various political subjects in a common project unlike conventional forms of political organization, as Lorenzo explained:

\begin{abstract}
We had to invent something else to mobilize a series of relationships, since we had the problem that we were collaborating with a lot of different groups and we wanted to do something with them. But obviously no one wanted to create a cartel, a board, the organization of the organizations. We knew that this would mean losing direction. We had to create a mechanism to involve these people.
\end{abstract}

Besides the cooperation enabled by pre-existing relationships among groups of activists, even ordinary people who were not socialized at the political level in a strict sense contributed to creating sticker cards. Daniela recalled:

There was this character, Piger Man, which is by a group from a suburb, friends of mine, who are not usually activists. But they took an interest and on that occasion they participated. [The creation of Piger Man provided] a form of relationship to contrast with human misery. [Piger Man was] Even [relevant] with regard to socialization in suburban areas, since they live in Baggio, on the outskirts of Milan.

The Imbattibili, like Serpica Naro, created strong, though temporary, relationships oriented towards the spreading of an awareness about precarity issues among a selected network of individuals with divergent political aspirations, yet who were also linked by a common short-term goal: the creation of the media sociali itself. In this they wree participating in a dynamic identified by McDonald, by which 'the production of culture $\ldots$ is itself the medium of action: where culture allows one to recognize the other as different, and constitutes the possibility of communication and the construction of subjectivity' (2002: 124).

Moreover, the construction of individual sticker cards that represented a particular issue of precarity, and the Imbattibili album, were crucial in making visible the scattered network, which in turn was reinforced by the experience of participation. The album, for instance, included the contact details of each activist group, such as the website and the e-mail address. According to the interviewee Laura, such visibility was important in order to maintain the presence and participation of smaller political groups in the Euro Mayday Parade:

The Mayday in 2004, with 100,000 people, impressed large political formations, which attempted to hijack the whole parade in 2005 . We started from this problem: how to mobilize the smallest groups, which would run away at the sight of FIOM with their activists and their flags ... 
Media activists distributed the Imbattibili album at the beginning of the Parade in 2005, while various trucks along the Parade route handed out sticker cards to participants, using the popular practice of sticker card collection to reach the less politicized demonstrators. Lorenzo pointed out that the Chainworkers Crew actively pursued this shift in communication tactics:

We thought to do a sticker cards album because the childish regression mechanism is a well known mechanism in the construction of enthusiasm ... and at the same time we used a mechanism that everyone instinctively recognizes in the sense that to collect sticker cards and complete an album is an instinctive mechanism.

As with the circulations of San Precario saint cards, activists exploited a popular culture object, the sticker card, to render the mechanism of diffusion easier and faster. Moreover, their catchy aesthetic and parodic language separate these kinds of media sociali from traditional social movement communications, such as leaflets and slogans. Media sociali like the Imbattibili or San Precario rest on a mechanism of popular culture subversion, generating objects that are only apparently neutral, and which aim to transmit a clear political message about precarity. The medium (sticker, album) and its political contents thus seem to be incommensurable in a subtle way, given that two different languages meet in the media sociali: the medium evokes a popular culture tradition, supposed to be non-political in its essence; the contents express radical ideas about precarity and implicitly propose a collective action frame in which irony and struggle are conjoined. This characteristic of the media sociali introduced to the Euro Mayday Parade a repertoire of action inspired by, and similar to, the tactics pioneered by the communication guerrilla and culture jamming political movements. This repertoire of action did not belong to all activist groups that participated in the construction of the long protest campaigns against precarity. ${ }^{30}$

It is probably for this reason that among other activist groups there was a certain degree of scepticism about the purported communicative potential of the Imbattibili. This opinion was particularly strong among radical trade unionists. In fact, when many unionists saw the Imbattibili for the first time during the Euro Mayday Parade in 2005, they did not clearly understand their meaning. Leonardo recalls, 'I noticed that at the

\footnotetext{
${ }^{30}$ Culture jamming is 'media hacking, information warfare, terror-art, and guerrilla semiotics, all in one. Billboard bandits, pirate TV and radio broadcasters, media hoaxers, and other vernacular media wrenches who intrude on the intruders, investing ads, newscasts, and other media artefacts with subversive meanings are all culture jammers' (Dery 1990: 1).
} 
beginning they looked at the Imbattibili and said: 'what are they, what has that got to do with work, with the unions ... they are different things. ${ }^{, 31}$

The main problems facing the Imbattibili and their circulations appeared to be translational and spatial, in that the radical trade union milieu operated with a different linguistic register and communication repertoire, and in different daily contexts and venues. Precarious workers represented by radical trade unions, such as the CUB or COBAS, are not acquainted with cards utilized as political communication tools. That said, while there was suspicion at first, the Imbattibili succeeded in partially overcoming the linguistic and communicative gap between two different political groups, as noted by one trade unionist, Domenico, by using irony and humour in the political message: 'it was a way to reflect on different kinds of precarity and this was a brilliant idea to some extent ... This element popularises, makes banal a campaign which is surely much more complex. Then, from this point of view it could also help ... it is also a way to joke and to show that precarity is everywhere.' Radical trade unionists generally regarded the Imbattibili as an unserious mode of speaking about precarity, rather than a means of political socialization. The traditional repertoire of communication-leaflets and internal e-mail — was considered more effective by radical trade unionists for whom struggles and political actions in workplaces spring from daily face-to-face contacts between precarious workers and their union representatives.

\section{Conclusions}

Media sociali are an innovative form of alternative media practice developed in Italy. A range of activist tactics characterize their creation and the reception. In the creation of media sociali the mechanism of political socialization and the consequent mechanism of social networking are at work. The construction process of the media sociali combines raising the awareness of precarious workers about their living and working conditions with the attempt to develop a social network able to mobilize against precarity. In this regard, the level of intervention by participants in media sociali is mainly political, in the sense that political socialization among precarious workers and the construction of productive social networks of activists and non-activists provide the basis for promoting and spreading political struggle. In the reception of media sociali the mechanism of

\footnotetext{
${ }^{31}$ Leonardo is a radical unionist of the SINCOBAS. The interview took place in his office in Milan on January 24, 2004.
} 
distribution allows the spreading of a novel imagery related to precarious workers and precarity in social, cultural and political contexts that are both directly and indirectly linked to activists involved in the Euro Mayday Parade. As a result of these processes, a mechanism of mutual recognition between activists and non-politicized precarious workers and people contributes to the broad social dissemination of the imagery of precarity.

Despite the importance of media sociali, there are few studies of the Italian alternative media, hence my intention here to relate media sociali to other alternative media practices developed in different social and political contexts. ${ }^{32}$ With this approach I am in agreement with many scholars of alternative media that 'we need to consider not only form and content, but the processes and relations that inform them and are in turn informed by them. The study of alternative media needs to interrogate identities and practices' (Atton 2002: 152). The usefulness of this suggestion is particularly evident when dealing with the actual use and understanding of the media sociali in the radical political spaces in which they were created, the Euro Mayday Parade. Three conclusions can be drawn from the analysis of the mechanisms behind the media sociali and their reception in the broader context of the Euro Mayday Parade. Each conclusion is linked to one of the three communication processes singled out by Atton (2002) when discussing the specific features of alternative media in comparison to other types of media, such as mainstream media.

The first conclusion is that media sociali imply 'transformed social relations, roles and responsibilities' (Atton 2002: 27) between readers and writers of alternative media. Serpica Naro is emblematic of this, since the creation of her identity and the organization of the fashion show included participants who were not usually involved in the production of media. Moreover, many participants were non-politicized precarious workers who became empowered by their experience. Serpica Naro was more than a successful media hoax. However, as I have argued, that reading was a common one among many activists who took part in the Euro Mayday Parade: they considered Serpico Naro as a non-repeatable, clever infiltration into the fashion system, rather than an empowering tool for precarious workers. The same activists had even more

\footnotetext{
${ }^{32}$ See note 6.
} 
difficulties in understanding the political meaning of the Imbattibili sticker cards that aimed to strengthen the links among the many small activist groups that had mobilized around precarity. Many activists saw the stickers merely as amusing responses to precarity. These difficulties point to the existence of different conceptualizations of communication and struggle within the same radical political outfit. They also highlight the problems that an activist group might confront in communicating the political meaning of its own media practices to other activists groups. Yet, while the successful distribution of the media sociali within the movement might be unquestioned, the distribution of their political value might be understimated, given that the process of dissemination might productively render visible differences among activist groups belonging to the same social movement network.

The second conclusion relates to the 'distributive use' (Atton 2002: 27) of media sociali. San Precario is exemplary here: its production fostered the distribution of new imagery about precarious workers. This distribution was particularly notable in the network of activist groups that sustained the Euro Mayday Parade, due to the existence of 'intramovement links' (McAdam \& Rucht 1993: 61). The dissemination of San Precario images was seldom a neutral social practice, since it implied a process of translation and re-adaptation of the same images. By travelling from one activist group to another, each with its own repertoire of action and political traditions, icons like San Precario were transformed, updated, and revised. As my analysis of the media sociali shows, it seems that the more activist groups engage themselves in these processes of translation and adaptation, the more the media sociali can be considered to be productive political media, and not simply as humorous tools or modes of comment. The most successful of the media sociali, indeed, has been San Precario. Different activist groups have used the icon in a range of struggles against precarity. Many of the people I interviewed stressed the political importance of San Precario imagery in representing precarious workers and their claims without institutional mediations by traditional trade unions and political parties.

The third conclusion concerns the development of 'horizontal linkages, networks' (Atton 2002: 27) in the process of creating alternative media. The Imbattibili sticker cards represented a network of activist groups and individuals mobilized on precarity and engaged in the Euro Mayday Parade. The stickers also functioned as a visual and 
material representation of living experiences that produced knowledge in order to draw social attention to precarious working and their living conditions. A similar dynamic occurred with the staged fashion show of Serpica Naro, which was sustained by a network of activists and precarious workers who were involved in the same alternative media practice. Both networks, however, worked under the necessary supervision of the activist group that developed the idea of the media sociali, the Chainworkers Crew. As a consequence, the networks that the media sociali created or fostered maintained a soft hierarchical structure. This highlights a challenge that activists groups continue to face when developing and engaging in alternative media practices: how to reconcile the horizontality of social relations among individuals and activist groups with the need for some kind of hierarchy and some degree of coordination within the network.

\section{Reference List}

Accornero, A. 2006, San Precario lavora per noi, Rizzoli, Milano.

Agrikoliansky, E. \& Sommier, I. (eds) 2005, Radiographie du mouvement altermondialiste, La Dispute, Paris.

Atton, C. 2002, Alternative Media, Sage, London.

Beck, U. 2000, The Brave New World of Work, Polity Press, Cambridge.

Botalnski, L. \& Chiapello, E. 2005, The New Spirit of Capitalism, Verso, London.

Chainworkers Crew 2001, ChainWorkers. Lavorare nelle cattedrali del consumo, DeriveApprodi, Roma.

Chainworkers Crew 2006, Reader. Available online: www.chainworkers.org/cw_reader [Accessed 16 February 2007].

Chainworkers Crew n.d.-a, Chi siamo. Available online: http://www.chainworkers.org/faq [Accessed 1 February 2008].

Chainworkers Crew n.d.-b, San Precario. Available online: http://www.chainworkers.org/SANPRECARIO/index_multi.html [Accessed 20 February 2007].

Chainworkers Crew n.d.-c, Serpica Story. Available online: http://www.serpicanaro.org/story [Accessed 25 February 2007].

Chainworkers Crew n.d.-d, Superflex. Available online: http://www.chainworkers.org/IMBATTIBILI/?hero=7 [Accessed 20 February 2007].

Couldry, N. 2000, The Place of Media Power: Pilgrims and Witnesses of the Media Age, Routledge, London.

Couldry, N. \& Curran, J. 2003, 'The Paradox of Media Power,' in Contesting Media Power: Alternative Media in a Networked World, (eds) N. Couldry \& J. Curran, Rowman \& Littlefield, Lanham, MD.

Couldry, N. 2004, 'Theorising Media as Practice,' Social Semiotics, vol. 14, no. 2, 3-16.

Curcio, A. \& Visco, G. 2005, 'Conflitti e precarietà urbane. L'EuroMayDay 2005 tra Milano, Parigi e Siviglia,' Paper presented at Convegno Annuale SISP, Università di Cagliari

Della Porta, D. 2007, 'The Global Justice Movement: An Introduction,' in The Global Justice Movement. Cross National and Transnational Perspectives, Della Porta (ed.) Paradigm Publisher, London.

Della Porta, D. \& Mosca, L. 2007, 'In movimento: "Contamination" in Action and the Italian Global Justice Movement,' Global Networks, vol. 7, no. 1, 1-27.

Della Porta, D. \& Rucht, D. 2002, 'The Dynamics of Environmental Campaigns,' Mobilization, vol. 7, no. $1,1-14$.

Downing, J. 2001, Radical Media: Rebellious Communication and Social Movements, Sage, Thousand Oaks, CA.

Dery, M. 1990, 'Culture Jamming: Hacking, Slashing and Sniping in the Empire of Signs.' Available online: http://www.markdery.com/archives/books/culture_jamming/\#000005\#more [Accessed 1 July 2008]. 
Duncombe, S. 1997, Notes from Underground: Zines and the Politics of Alternative Culture, Verso, London and New York.

Euromayday Network 2004, Euromayday. Available online: http://www.euromayday.org/mayday004/ [Accessed 20 February 2007].

Fumagalli, A. 2006, Lavoro. Vecchio e nuovo sfruttamento, Edizioni Punto Rosso/Carta, Roma.

Fumagalli, A. 2007, 'Precarietà,' in Parole di una nuova politica, (ed.) Transform! Italia, XL Edizioni, Roma, 27-34.

Gallino, L. 2007, Il lavoro non è una merce. Contro la flessibilità, Laterza, Roma.

Global Project 2004, 30 ottobre '04: apparizioni/azioni dirette/miracoli di San Precario. Available online: http://www.globalproject.info/art-2519.html [Accessed 23 February 2005].

Grispini, M. 2006, 1977, 2nd edition, Manifestolibri, Roma.

Langlois, A. \& Dubois, F. (eds) 2005, Autonomous media: Activating Resistance and Dissent, Cumulus Press, Montreal.

Mcadam, D. \& Rucht, D. 1993, 'The Cross-National Diffusion of Movement Ideas,' Annals of the American Academy of Political and Social Science, vol. 528, no. 1, 56-74.

Mcdonald, K. 2002, 'From Solidarity to Fluidarity: Social Movements Beyond "Collective identity." The Case of Globalization Conflicts,' Social Movement Studies, vol. 1, no. 2, 109-128.

Melucci, A. 1996, Challenging Codes : Collective Action in the Information Age, Cambridge University Press, Cambridge and New York.

Meikle, G. 2007, 'Stop Signs: An Introduction to Culture Jamming,' in The Alternative Media Handbook, (eds) K. Coyer, T. Dowmunt \& A. Fountain, Routledge, London and New York.

Neilson, B. \& Rossiter, N. 2005, 'From Precarity to Precariousness and Back Again: Labour, Life and Unstable Networks,' Fibreculture, no. 5. Available online: http://journal.fibreculture.org/issue5/neilson_rossiter.html [Accessed 1 July 2008].

Peretti, J. 2001, Culture Jamming, Memes, Social Networks, and the Emerging Media Ecology. The "Nike Sweatshop Email" as Object-To-Think-With. Available online: http://depts.washington.edu/ccee/polcommcampaigns/peretti.html [Accessed 03 July 2008].

Reload Video Crew 2004, San Precario va alla COOP. Available online: http://www.ngvision.org/mediabase/301 [Accessed 1 June 2004].

Rete Regionale Contro La Precarietà E La Legge 30 2005, Progetto di legge di iniziativa popolare sul diritto di reddito sociale. Available online: http://www.redditolombardia.org/html/pivot/entry.php?id=5\#body [Accessed 20 February 2007].

Rodriguez, C. 2001, Fissures in the Mediascape. An International Study of Citizens' Media, Hampton Press, Creskill, NJ.

San Precario n.d., San Precario Available online: www.sanprecario.info [Accessed 10 December 2007].

Tarì, M. \& Vanni, I. (2005) 'On the Life and Deeds of San Precario, Patron Saint of Precarious Workers and Llives'. Fibreculture, no. 5. Available online: http://journal.fibreculture.org/issue5/vanni_tari.html [Accessed 1 July 2008].

Tilly, C. 1978, From Mobilization to Revolution, Addison-Wesley, Reading, MA.

Tilly, C. \& Tarrow, S. G. 2006, Contentious Politics, Paradigm Publishers, Boulder, CO.

Vanni, I. 2007, 'How to Do Things with Words and Images: Gli Imbattibili,' in Images and Communities. The Visual Construction of the Social, (eds) M. Stocchetti \& J. Sumalia-Sappanen, University of Helsinki Press, Helsinki, 147-170.

Waltz, M. 2005, Alternative and Activist Mmedia, Edinburgh University Press, Edinburgh. 